\title{
JOÃO FRANCISCO LISBOA E UMA HISTÓRIA DO PRESENTE NO IMPÉRIO: O CASO DE PARTIDOS E ELEIÇÕES NO MARANHÃO
}

\author{
JOÃO FRANCISCO LISBOA AND A HISTORY OF THE PRESENT IN \\ THE EMPIRE: THE CASE OF PARTIDOS E ELEIÇÕES NO \\ MARANHÃO
}

\begin{abstract}
Ana Priscila de Sousa Sá ${ }^{1}$
RESUMO: O artigo tomou o folheto Partidos e eleições no Maranhão (1843) de João Francisco Lisboa como objeto para investigar o lugar de uma história do presente no Brasil do século XIX. Publicado no primeiro volume do Jornal de Tímon, o folheto destrinçou o processo eleitoral na Província do Maranhão com suas intrigas políticas, lutas entre as facções locais para alcançar ou conservar a influência sobre as lideranças do governo da província. Nesse contexto, não obstante o pouco crédito que essa modalidade possuía à época, bem como dentro do espaço de produção do conhecimento histórico mais importante do Império, o Instituto Histórico e Geográfico Brasileiro (IHGB), é possível fazer uma leitura sobre como Lisboa tratou eventos recentes ocorridos na Província do Maranhão, fazendo deles matéria para escrever história.
\end{abstract}

PALAVRAS-CHAVE: Lisboa; historiografia brasileira oitocentista; história do presente.

ABSTRACT: The article took the pamphlet Partidos e eleições no Maranhão (1843) by João Francisco Lisboa as an object to investigate the place of a history of the present in Brazil in the 19th century. Published in the first volume of the Jornal de Timon, the pamphlet unraveled the electoral process in the Província do Maranhão with its political intrigues, struggles between local factions to achieve or maintain influence over the leadership of the provincial government. In this context, despite the little credit that this modality had at the time, as well as within the space of production of the most important historical knowledge of the Empire, the Instituto Histórico e Geográfico Brasileiro (IHGB), it is possible to read about how Lisbon dealt with events recent events in the Província do Maranhão, making them material for writing history.

\footnotetext{
* O artigo faz parte da pesquisa em andamento de Doutorado em História desenvolvida na Universidade Federal do Maranhão, com financiamento da FAPEMA.

1 Doutoranda em História pela Universidade Federal do Maranhão - UFMA. Bolsista FAPEMA. E-mail: priscilareds@hotmail.com. ORCID: http://orcid.org/0000-0002-0048-280X.
} 
KEYWORDS: Lisboa; historiografia brasileira oitocentista; história do presente.

\section{Introdução}

Figura reconhecida da imprensa maranhense do século XIX, João Francisco Lisboa exerceu cargos políticos e também se lançou aos estudos históricos. Desacreditado da vida política, na qual atuou junto ao grupo liberal, e cansado das lutas pelas páginas do jornalismo político na província, em sua última década de vida se dedicou a escrever sobre a história do "obscuro canto do mundo" (LISBOA, 1864, p. 5) que habitava. A principal obra historiográfica, Jornal de Tímon, deu-lhe notoriedade entre os letrados do Império e com ele seu nome foi indicado por Gonçalves Dias para o Instituto Histórico e Geográfico Brasileiro (IHGB). Os dez primeiros números foram publicados entre 1852 e 1853 ainda no Maranhão, de onde nunca saíra até então. Em 1855, Lisboa se mudou para o Rio de Janeiro, nesse momento já compunha o quadro de sócios do Instituto. Meses depois, foi nomeado para ser pesquisador do Instituto em Portugal com o encargo de copiar documentos relativos à história do Brasil, função anteriormente assumida pelo comprovinciano Gonçalves Dias. Desse modo, os números 11 e 12 do Jornal saíram só em 1858, direto da capital portuguesa ${ }^{2}$.

Este artigo se debruçou sobre o folheto Partidos e eleições no Maranhão (1853), publicado no Jornal. Tratava-se de um estudo sobre a situação política/partidária da Província do Maranhão em meados do século XIX. Sob o pseudônimo Tímon, referência ao homônimo grego famoso pela misantropia, Lisboa colocou as eleições como foco privilegiado para análise, esboçando com vivas cores o cenário da política provincial cujos partidos usavam como instrumentos de ação os Presidentes de Província, os jornais e as próprias eleições. Para Maria de Lourdes Janotti (1977, p. 131), Partidos e eleições... era, antes que parte da produção histórica de Lisboa, um testemunho de uma época. Já no livro de Rita Santos, apareceu como um discurso de moral

\footnotetext{
${ }^{2}$ A grafia dos documentos foi atualizada.
} 
política sob o pretexto de fazer história (SANTOS, 2000, p. 242). Neste artigo, tomei o folheto como exemplo da prática historiográfica de Lisboa, ponderando que no momento em que foi escrito não havia um modelo único de se escrever história no Brasil oitocentista, possibilitando uma diversidade de formas e temas.

O intento era escrever uma história da província para a província, declarou que das pequenas províncias "bastam simples e modestas memórias, que sirvam depois ao trabalho complexo que compreenda o todo" (LISBOA, 1865 , p. 24). A despeito da aparente modéstia do autor, é fato que não acalentou o projeto de escrever uma história geral como o fez Francisco Adolfo de Varnhagen, por exemplo, gênero muito apreciado no período e uma das razões para a criação do Instituto.

Pintando o quadro da corrupção eleitoral e iluminando aspectos como a atuação da imprensa, os jogos de poder e as lutas entre as facções locais, Lisboa realizou um exercício de escrita da história de sua província natal enfocando eventos recentes, realizando com isso um trabalho que ajuda a refletir acerca de uma questão que permeia os estudos sobre historiografia no Brasil oitocentista: o lugar da história do presente. A modalidade não era recomendada pela proximidade temporal, mas nem por isso deixou de ser praticada mesmo no interior do IHGB, espaço por excelência da produção histórica da época. Assim, antes de adentrar o folheto faz-se necessário discutir qual o lugar do presente nas narrativas orientadas pelo Instituto.

\section{A "arca do sigilo"}

Em dezembro de 1847, Francisco Freire Allemão fez a seguinte proposta em sessão do IHGB:

Proponho que no Instituto haja uma arca fechada com duas chaves, uma das quais guardará o Exmo. Ministro do Império, ou o diretor do Arquivo Público Nacional, para que nela se conservem debaixo de sigilo as notícias históricas contemporâneas que alguém queira enviar ao mesmo Instituto, notícias que virão lacradas em cartas, e só serão abertas no tempo em que seu autor o determinar [...]. (IHGB, 1847, p. 567) 
A proposta de criar o que logo passou a ser chamada "arca do sigilo" foi um passo maior rumo à materialização do que já era aventado como ideia. Pelo que consta nas atas das sessões do Instituto nos anos seguintes, a arca não chegou a ser construída e o assunto foi escasseando entre os sócios. Porém, o fato de ter sido aceita em fevereiro de 1850 por uma comissão formada pelo próprio Freire Allemão, Manoel de Araújo Porto Alegre e Manoel Ferreira Lagos, evidencia o caráter extraordinário que o assunto gozava no interior da agremiação. Mas, em que consistia tal "arca do sigilo"? Por que segredar "notícias históricas contemporâneas"?

$\mathrm{O}$ arquivo secreto deveria ser feito de madeira ou metal para guardar a documentação com o máximo de segurança. Observe-se que havia uma atmosfera de oficialidade na proposta, uma das chaves ficaria com um Ministro, portanto, uma figura proeminente do cenário político do Império. Deveria haver toda uma ritualística para a abertura da arca, assunto debatido em sessão, tudo com o propósito de guardar sigilo até chegar o momento de revelar tais cópias. A partir do parecer da comissão é possível avaliar outros aspectos que permeava essa proposta:

Escritos há, certamente, muito úteis e preciosos para a história de um país, cuja imediata impressão pode acarretar, além de grandes desgostos a seus autores, incalculáveis perturbações, e comprometer não só a paz interna, como a externa; e outros, que envolvendo personalidades contemporâneas e descarnando os fatos, ou divulgando segredos, trariam um sem número de inimizades e deslocações pessoais, mormente em épocas de transição, e num país como o nosso, onde as bases de uma longa experiência não podem ainda frutificar, e onde a tolerância das nações velhas ainda não chegou. (IHGB, 1850, p. 133)

A avaliação dos sócios admite ao menos duas camadas de leitura. Havia o receio de uma interpretação dos fatos impregnada de paixões pessoais ou regionais do historiador. Pairava a preocupação com a narração imparcial. Além de uma eventual perturbação interna, trazer a público determinados documentos podia provocar animosidades entre o Império e outros países, Portugal notadamente, e uma crise externa naquele momento não era bom cenário, o que demonstra o lado político que a ideia da arca carregava consigo. Nesse sentido, 
segredar significava também proteger a política e o Estado imperial (MALEVAL, 2013, p. 2). Por outro lado, na dupla função de letrado e político, os sócios do IHGB não se viam autorizados a falar do seu tempo por em boa parte corresponder a sua própria experiência (TIBURSKI, 2011, p. 91). Num campo historiográfico ainda não consolidado e dada a fragilidade dos critérios de avaliação da produção da época, havia esse desencorajamento pelas dificuldades em termos epistemológicos e políticos. Pelo entendimento de que o interesse muitas vezes substituía a razão, também a imprensa era tida como parcial, daí seu uso como fonte ser vista com reservas.

O Instituto assumia a função de lugar de produção do discurso histórico que permitia e proibia. Como assinalado por Michel de Certeau (2017, p. 63), "a pesquisa está circunscrita pelo lugar que define uma conexão do possível e do impossível", tornando possível certas pesquisas e impossíveis outras tantas. Importa destacar que a arca teria prazo de validade, já Freire Allemão propunha que seu fechamento fosse temporário, seria aberta em um tempo já entendido como seguro, tempo que a verdade ali contida podia ser revelada sem maiores constrangimentos. O Instituto parecia querer promover a ideia de que o conteúdo da arca era a verdade sobre aquele presente, nas palavras de Lucia Guimarães, fazia-se uma "idealização do futuro à custa da manipulação do presente” (GUIMARÃES, 1995, p. 388).

Mesmo com as transformações conceituais que se acentuaram a partir da década de 1830, o processo de historicização (ARAUJO, 2008, p. 103) e crescente descrédito do antigo modelo de história magistra vitae em alguns contextos, a concepção de história que tinha lugar no Instituto era a de que ela tinha uma função judicativa. Havia uma concomitância entre uma forma de escrita da história mais atualizada com os pressupostos do período, uma história "científica", e outra forma cultivada desde a Antiguidade, ainda que esse modelo antigo não fosse mais tomado no sentido de imitação. Em trecho do mesmo relatório, os avaliadores ponderaram que a história seria "o juiz póstumo do caráter de todos os autores principais da cena do nosso mundo", ao revelar "fatos que tornariam a história obscura, forçando os escritores futuros a 
tatearem no mundo das conjecturas e das probabilidades" (RIHGB, 1850, p. 134). O trabalho do historiador se assemelharia muito ao do juiz que analisava e sentenciava. À história cabia desvendar o desconhecido, explicar os pontos obscuros, auxiliar o escritor do futuro escoimando as dúvidas até então existentes. Desse modo, a questão de tratar de assuntos contemporâneos passava também pelo próprio ato da escrita.

Pensando a construção da disciplina histórica ao longo do século XIX, a prática dessa modalidade era vista com larga reserva, entendia-se que o historiador "distanciado estaria proibido de escrever uma História do presente, pois ela, no máximo, ajudaria a desencadear o partidarismo" (KOSELLECK, 2016, p. 204). Esse freio epistemológico, no entanto, não conduziu a uma impossibilidade. Um trabalho a respeito de um evento recente que recebeu aval e foi premiado pelo Instituto foi a "Memória Histórica e Documentada da Revolução da Província do Maranhão desde 1839 a 1840” (1848) de Gonçalves de Magalhães. A comissão designada para avaliar a obra celebrou a exposição metódica e lúcida, e a imparcialidade do poeta que, na condição de secretário do governo, tinha à disposição documentos oficiais e peças autênticas que possibilitaram "chegar ao conhecimento apropriado das cenas" (IHGB, 1847, p. 425) da Balaiada. A apreciação do trabalho de Magalhães é ainda oportuna para analisar outro aspecto que, a despeito do enfraquecimento ao longo do século, permanecia amplamente utilizado na produção histórica da época: a testemunha ocular. No parecer dos sócios responsáveis pela avaliação da "Memória", o poeta teria sido:

Estranho aos partidos, que lutavam entre si nesse período calamitoso da história da província do Maranhão, ele pode apreciar o encadeamento de causas diversas, que trouxeram consigo aquela medonha explosão da guerra civil e da anarquia, e distinguir a natureza e diversidade de elementos que a formavam. (IHGB, 1847, p. 425)

Pela ótica dos pareceristas, o não envolvimento do autor com os partidos que disputavam a cena política da província conferia o caráter de isenção recomendado para o ofício, não poderia ser acusado de parcialidade, nem de tentativa de privilegiar uma leitura dos fatos que coadunasse com uma posição 
pessoal em detrimento de outra mais "verdadeira". Ao lado da utilização de documentação oficial da época, já entendida como dotada de um estatuto de verdade, a condição de testemunha ocular do autor era também importante para uma narração mais próxima da realidade do ocorrido na Província do Maranhão, legitimando o discurso: ele viu. Estar presente na cena ainda era condição de saber e poder entregar melhor uma narrativa a respeito.

Escrever sobre eventos recentes recebeu muitas vezes a censura do IHGB, a prática de arquivar ou vetar documentos considerados impróprios pelo recorte temporal escolhido foi procedimento adotado desde o início dos trabalhos da agremiação fundada em 1838. No entanto, o caso da "Memória" ofertada por Gonçalves de Magalhães demonstra que o fato de uma história do presente não ser vista com bons olhos pelos consócios não significava que sua produção não existisse ou pudesse ser bem recebida pelo próprio Instituto. Por essa ótica, a "arca do sigilo" pode ser compreendida como um reconhecimento da ausência de maturidade política e epistemológica para escrever sobre o próprio tempo (CEZAR, 2013, s/p). O trabalho de João Francisco Lisboa permite abordar essa questão por outra chave.

\section{A "história pátria" maranhense}

Assim Lisboa caracterizou sua época: "Que a nossa situação é das piores, senão de todo péssima e desesperada, é cousa que já não pode sofrer dúvida e contestação" (LISBOA, 1864, p. 407), denotando aí a pauta de Partidos e eleições..., a narração da estrutura política provincial em suas contradições. Pelo fenômeno das eleições, o diagnóstico e a compreensão pragmática do drama provinciano denotava uma falsa aparência das instituições, dos partidos, da presidência, do povo e das próprias eleições (SOARES, 2002, p. 4-30). Importa assinalar que o folheto se seguiu à análise das Eleições na Antiguidade, eleições na Idade Média, eleições na Roma Católica, Inglaterra, Estados Unidos, França, Turquia. Lisboa via no Maranhão moderno a repetição de velhos hábitos encontrados em outras 
sociedades e épocas, ainda que o uso da comparação histórica fosse feita de modo pouco articulado ou explicado, não expondo para o leitor que se tratava de processos diferentes. Também não deixava explícito que o método da comparação ali experimentado servia para defender seu ponto de vista sobre uma realidade historicamente datada, a do Maranhão de seu tempo, e que não era igual àquelas que precederam sua análise sobre a província. Provavelmente por esse motivo anotou que o fim primário do trabalho seria "sempre a pintura de nossos costumes políticos" (LISBOA, 1864, p. 7). Mesmo recuando séculos para movimentar sua análise, era para sua terra que não parava de olhar.

Gostaria de ressalvar uma vez mais que Lisboa não era sócio do Instituto à época da publicação dos primeiros números do Jornal de Tímon, logo, não se pode afirmar que seu trabalho naquele momento (ou mesmo posteriormente) se preocupava em seguir as diretrizes da agremiação instalada na Corte, mesmo tendo acesso à Revista Trimensal e a citando eventualmente ao longo de sua obra historiográfica, mas sem chegar a publicar nela.

Publicado nos $\mathrm{n}^{\circ}$ II e III do Jornal de Tímon, em Partidos e eleições... Lisboa fez um panorama da situação político-partidária maranhense de sua época. A escolha do tema "eleições" não foi de modo algum aleatória, era um assunto que gerava bastante interesse entre os comprovincianos e fazia parte do arsenal do autor que, ligado aos liberais, foi Deputado e secretário de governo na administração de Antônio Pedro da Costa Ferreira, futuro Barão de Pindaré. Conforme já ponderado por Maria de Lourdes Janotti (1977, p. 69), o significado de Partidos e eleições... só pode ser compreendido confrontando-o com a vida política e jornalística, e a situação econômico-social provincial de meados do Oitocentos.

O traço ético foi uma constante na obra jornalística e histórica de Lisboa e nesse folheto ele ficou bem marcado. Na trama novelística que urdiu com vivas cores, um dos personagens mais importantes foi o Presidente de Província, caracterizado como um carreirista, as eleições apareciam marcadas pela violência e os partidos se digladiavam por um assento junto ao Governo, cada um editando um periódico em defesa de suas ideias. Com invulgar 
perspicácia, Lisboa analisou as mazelas morais dos políticos em solo maranhense, o que, em sua opinião, repetia-se em todo o Império. Nesse sentido, Janotti (1977, p. 77) observou a ligação entre o conteúdo do Jornal e artigos da Crônica Maranhense, jornal editado por Lisboa entre 1838 e 1840, mas não enveredei por aí nesta investigação, basta o apontamento de que a matéria de que tratava o folheto já era de longe trabalhada pelo autor.

Falando do momento que precedia a quadra eleitoral, escreveu uma história do presente de sua província. Explique-se, Lisboa não deixou explícito ao longo do trabalho sua intenção consciente de escrever uma história do presente como se pode pensar em termos atuais. Escrever sobre acontecimentos recentes tinha mais a ver com suas preocupações de cariz moral, da história como instrumento para ajudar a reformar os costumes da província, do que uma escolha epistemológica, o que exigiria uma reflexão teórica mais profunda que não caracterizava propriamente a historiografia da época. Para tanto usou de alguns recursos para que determinadas personalidades reais não se reconhecessem totalmente nas personagens da narração. Um procedimento foi o ocultamento de datas e a utilização de nomes fictícios, como se pode ver no seguinte excerto: "Corria o ano de 184.., e esta heroica província gozava então da honra talvez pouco apreciada de ser presidida pelo excelentíssimo senhor doutor Anastácio Pedro de Moura e Albuquerque" (LISBOA, 1864, p. 163). Em outra ocasião ocultou o nome de uma personalidade que seria da confiança do Presidente: "Um dia contudo em que S. Exc. escrevia ao seu ministro predileto [...]" (LISBOA, 1864, p. 168). A omissão da data completa e a colocação de um nome irreal isentava Lisboa de ter de responder a eventuais retaliações.

Todavia, os personagens eram delineados com as características que atribuía ao político que estivesse exercendo a função, qual seja, já que a ideia do folheto era traçar um panorama da dinâmica política local. Na intenção do autor, o nome poderia ser fictício, mas as atitudes eram bastante reais e recorrentes. 
Para traçar seu quadro, garantia se apoiar nos jornais da época e na experiência que tinha das "coisas" maranhenses, fato que todos os contemporâneos poderiam atestar por observarem o mesmo:

eu tenho por mim não só o testemunho universal de uma grande cidade, senão também a autoridade fidedigna do porteiro do tesouro e do almoxarife do hospital, a quem, prevendo já estas dúvidas, fui consultar, na sua qualidade de testemunhas oculares, pois sei que como empregados ou pretendentes que eram, assistiram a diversos atos a que S. Exc. também era presente. (LISBOA, 1864, p. 187)

A confiança nos olhos e ouvidos da testemunha inspirava no autor a garantia de autoridade do relatado, mas não apenas outra pessoa podia lhe servir de base para a narração dos episódios da "epopeia provincial" que se dispunha expor ao escrutínio público. Em outro momento narrou algo que ele mesmo presenciou e podia dar o testemunho: "referirei um fato de que fui testemunha ocular" (LISBOA, 1864, p. 203). O fato em questão foi uma visita ao palácio do governo, momento em que pode observar a singeleza do ambiente interior da moradia do Presidente da Província, contrastada com a aparente grandeza externa do prédio. Calcado nos testemunhos, timbrava que eles o "fizeram ver com argumentos palpáveis, eloquentes e sem réplica, que tudo quanto se me havia informado era não só a pura verdade, senão muito verossímil e possível" (LISBOA, 1864, p. 187), colocando a verdade também no terreno da verossimilhança e da possibilidade. Probabilidade, plausibilidade e conjecturas foram invocadas pelo autor para reforçar seus argumentos. De forma alguma lhe pareceu fantasioso o que seus informantes relataram, eles viram, ouviram e reproduziram com riqueza de detalhes, o que se lhe apresentava suficiente a ponto de recordar que muitos outros nomes andavam esculpidos nas "tábuas da história" e ninguém ousava pô-los em dúvida.

Se a documentação lhe impunha limites, restava perscrutar o que se vira e ouvira. Tímon filtrou o que considerava mais interessante para o público assinante, afirmando não fugir à realidade do ocorrido e se amparando em outras fontes porque, como lembrou Hartog (2013, p. 13-14), a autópsia carecia de validação por outro meio. Nesse caso, Tímon se dizia baseado em 
documentos e nos jornais da época. No Prospecto que introduziu o volume sobre as eleições na Antiguidade, declarou que se seus quadros foram sombrios a justificação estava "no próprio jornalismo contemporâneo, onde a cada passo deparo as pinturas mais tenebrosas e medonhas da depravação e opróbrio dos nossos tempos" (LISBOA, 1864, p. 12), colocando os periódicos como fonte fidedigna capaz de corroborar as opiniões ali expressas. Se usadas para informar e entreter o público do periódico - demonstrando uma aproximação com o modelo de escrita da história compilatório, de caráter mais comercial e destinado a leitores não especializados (ARAUJO, 2015, p. 365-400) - o julgamento daquelas ações caberia à posteridade "pela voz imparcial e severa da história" (LISBOA, 1864, p. 202).

Foi com essa certeza da verdade do que estava relatando que em vários momentos Lisboa assumiu o papel de juiz do tribunal histórico, ainda que afirmasse delegar essa função à posteridade ou ao leitor do periódico. Antes de chegar o tempo da posteridade fazer seu trabalho de revisitar o que estava debaixo de camadas da história da província, Lisboa já aproveitou a narrativa para expor seus próprios julgamentos. Consciente da função dos documentos, frequentemente se tornou fiduciário de suas afirmações (BATALHONE JR., 2003, p. 5). Também aqui se processava o entendimento de uma função judicativa da história, e adicionava à sua a opinião dos leitores buscando imprimir um efeito de verdade. Nesse âmbito, a participação do leitor foi bastante requisitada ao longo de Partidos e eleições..., como no excerto abaixo:

O que mais disseram e fizeram naquela ocasião, deixa Tímon à perspicácia, e sobretudo à grande experiência do benigno leitor, - amestrado sem dúvida em todos estes meneios da política provincial, para que o imagine e aprecie como lhe parecer [...] (LISBOA, 1864, p. 181)

Lisboa se referia aos três dias que se passaram entre a demissão de Moura e Albuquerque e a posse oficial do novo Presidente, Bernardo Bonifácio Montalvão de Mascarenhas. Curto período utilizado pela antiga administração para chover portarias e patentes, os "meneios" da política provincial. A imaginação do leitor experiente nas "coisas" maranhenses foi conclamada outra vez para concluir a respeito da narração que encetara de certa reunião entre 
lideranças políticas da capital São Luís, deputados e outros influentes do interior da província. Após expor um diálogo que teria acontecido entre tais cavalheiros, suas maquinações para ganhar a confiança do novo Presidente antes da oposição, assinalou que "Não é possível a Tímon acompanhar esta boa gente em toda a sua conversa; o que se acaba de reproduzir dará ideia do mais que deixo no tinteiro" (LISBOA, 1864, p. 183).

Dentre as implicações do uso desse procedimento, dois se apresentam em primeiro plano: o caráter de verdade que Lisboa buscava imprimir à sua narrativa e o julgamento prévio das ações que se desenrolavam na mesma. Ponderou:

Tímon já está receando que alguém o acuse de tomar o tempo a seus leitores, com frioleiras e trivialidades, mas a verdade histórica não exige menos; e quantos têm alguma experiência das nossas coisas sabem que nada invento ou altero, antes levo o escrúpulo e o amor da verdade a tão alto ponto, que extratando os jornais do tempo, conservo fielmente não só as ideias, senão o estilo e a frase. (LISBOA, 1864, p. 193-194)

Lisboa apresentou em seu trabalho as três características apontadas por Rodrigo Turin que identificariam o ethos do historiador no Brasil oitocentista, a saber, a sinceridade, a instrumentalidade e a cientificidade (TURIN, 2009, p. 14). O autor fazia questão de reiterar que ali estava narrando a "verídica história da campanha eleitoral" sob o ponto de vista moral e político" e com isso talvez teria deles "ocasião para ensino e emenda, se é possível haver emenda, em um estado tão caído e malparado como o nosso" (LISBOA, 1864, p. 342). Isto é, o propósito da obra era concorrer para a reforma dos costumes provinciais, vistos como corrompidos, e não só os costumes eleitorais, mas os da sociedade maranhense como um todo.

Já se sentindo "por antecipação absolvido no tribunal de uma opinião esclarecida, como já o está pela sua própria consciência” (LISBOA, 1864, p. 428), avaliou que a política nas províncias se cifrava em trivialidades, intrigas, insultos e adulações ao poder que caía e se erguia, respectivamente, e na cópia de fórmulas políticas que não se adequava a realidade local. O juízo que fazia de tudo não dispensava os personagens da história que contava, uma das 
características da narração de Lisboa foi a adjetivação daqueles. A seguir, a descrição que fez de Montalvão de Mascarenhas:

o exm. Bernardo Bonifácio tinha umas maneiras tão francas e
afáveis com seus assomos de reserva e gravidade ao mesmo
tempo, uns ademanes tão desafetados, e nada menos tão
compostos, um falar tão culto, natural e fácil, um andar tão
firme e seguro, não obstante o arqueado das pernas, um
termo enfim tão senhoril em toda sua pessoa, que acareava
sem detença as simpatias e o respeito de quantos o
comunicavam. (LISBOA, 1864, p. 187-188)

A caracterização do Presidente da Província incluía citar minúcias como a impostação da voz e até a forma de andar, como se quisesse oferecer um perfil completo, físico e psicológico do personagem sobre o qual ora se debruçava. Tímon via na descrição de aspectos que poderiam ser consideradas banalidades por outros tantos um caminho rumo ao entendimento dos comportamentos e ações daquelas figuras de proa da política provincial. O excerto ainda permite perceber a tônica irônica do autor presente ao longo de todo o folheto. Para Jussara Silva (2017, p. 29), a presença da ironia no Jornal correspondia a um traço do estilo de Lisboa, uma marca de sua narrativa, que se apresentava tanto na pintura de cenários coletivos, quanto de cenas particulares, como a descrição acima de Montalvão de Mascarenhas.

Em diversos momentos usou da ironia ácida para (des)qualificar os dotes intelectuais de influentes locais como o conselheiro Arthur, "uma perfeita nulidade, lembrado, não obstante, e efetivamente aproveitado para todos o empregos provinciais, nos quais nada fazia que luzisse e aparecesse", e dos bacharéis que voltavam para casa como "verdadeiros doutores à mexicana" (LISBOA, 1864, p. 233-250). Como estilo historiográfico, a ironia o permitia denunciar aquele mundo distorcido que confundia o bem com o mal. Com isso, as adjetivações, a pontuação e os grifos em itálico no texto orientavam e tentavam convencer o leitor, conquistando-o para o campo que defendia. Em atitude séria, Tímon revelou a verdade cômica da ação partidária do Maranhão oitocentista (SANTOS, 2000, p. 167).

A tríade da corrupção generalizada se completava com os partidos e a imprensa da província. Em sua ótica, o jornalismo provincial era estéril, 
impotente e maldizente, só servindo para expor os vícios e as misérias da sociedade. Os partidos - se assim pudesse chamar posto a falta de diferenciação mais substancial entre os vários grupos que disputavam a atenção e a generosidade do governo - eram inúteis, sem força moral, quando não nocivos e incapazes do menor bem. Pela imprensa política os partidos exalavam e vertiam seus maus humores, pois mesmo quando não insultava ou caluniava, alimentava-se "de incessantes personalidades, despendendo exclusivamente no louvor e vitupério de certas e determinadas individualidades toda a seiva e vigor de que é dotada" (LISBOA, 1864, p. 361). Sem "dúvida” ou "contestação" que valesse, já dava o veredito final: converter as presidências em cargos puramente administrativos, despojados de caráter político.

Demonstrando uma modéstia que precisa ser avaliada com cautela dado o verniz sarcástico do texto, o autor abria seu ateliê confessando que:

Este pobre Tímon recua, hesita, flutua e duvida; e confundido e perturbado pelas maravilhas que cada dia se lhe antolham, ou humilhado pela própria insuficiência, se esquivaria calado ante estes formidáveis assuntos, se lhe não acudisse o expediente de aventurar acerca deles. (LISBOA, 1864, p. 431)

$\mathrm{O}$ ato de escrever sobre aquele assunto foi apresentado por Lisboa quase como uma obrigação moral. Obrigação que assumia como alguém que tinha conhecimento suficiente da situação política provincial, posto estar envolvido nesse ambiente desde a juventude e nele travado tantos embates com a oposição e mesmo com correligionários do Partido Liberal. Ao lado da instrumentalidade que tal narração poderia ter na reforma dos costumes, a confissão das dúvidas que teria sobre o trabalho de escrita se apresentava como mostra da sinceridade do autor, mas também como certa "falha" no outro critério definidor desse ethos, a cientificidade. Lisboa chegou mesmo a duvidar da originalidade dos trabalhos de seu tempo, dizendo que "A única invenção hoje possível consiste toda na felicidade e oportunidade da aplicação; e ainda isto mesmo não é dado a todos", por isso ali ele "extrata e copia, transformando e aplicando as cópias às cousas e aos homens do seu tempo. Nada mais, nada menos" (LISBOA, 1864, p. 13). 
Um contemporâneo que fez uma crítica ao trabalho de Lisboa nesse sentido foi Varnhagen. No livro "Os índios bravos e o Sr. Lisboa" (1867), o paulista avaliou a postura daquele como imprópria para um historiador, dada a demonstração de que não estava seguro do conteúdo que veiculava em seu periódico. Cumpre assinalar que esse debate teve lugar após a crítica de Lisboa ao tratamento dado por Varnhagen aos indígenas na "História Geral do Brasil" (1854). Tomando conhecimento da Nota C do Jornal de Tímon, o cunhado de Varnhagen Frederico Augusto Pereira de Morais publicou em Portugal o folheto "Diatribe contra a timonice do Jornal de Timon Maranhense acerca da História Geral do Brasil do Sr. Varnhagen” (1859). A "resposta” do historiador paulista só foi publicada em 1867 e não teve tempo de ser lida pelo maranhense, que falecera em 1863.

$\mathrm{Na}$ ótica de Varnhagen, Lisboa mostrava inexperiência com o trabalho de arquivo, ou mesmo a falta de documentação suficiente para um juízo dos fatos. A aparente falta de certeza revelada por Lisboa em algumas partes da narrativa, quando falou em hesitar, recuar, podia caracterizar certo amadorismo num contexto de profissionalização do trabalho do historiador. Na época de uma história científica, pouco espaço era reservado às dúvidas quais fossem.

Declarou Varnhagen acerca da escrita do maranhense:

Deus livre o Império do Brasil, de que a sua história, de menos de quarenta anos, caísse nas mãos de Timon, e que, segundo sua tendência, e agarrando-se com maior predileção ao lado desfavorável dos fatos, nos venha apresentar em seu perigoso estilo fascinador (VARNHAGEN, 1867, p. 14).

Defendendo-se da censura, Varnhagen acusou Lisboa de distorcer trechos da "História Geral" em sua Nota C para esquadrinhar os fatos a seu favor. Criticou o que chamou de "estilo fascinador", por ele entendido como prejudicial ao bom exercício de escrita da história do Brasil, pois um historiador comprometido jamais perderia de vista o princípio da imparcialidade. $\mathrm{Na}$ fala de Varnhagen, a juventude do país independente se confundia com a juventude da história a ser escrita com todo cuidado e método atualizado com o século que viviam. A despeito da desconfiança de análises como a de Varnhagen, Lisboa reiterava que oferecia ali um relato histórico, com personagens históricos, 
escrito por um historiador comprometido com a verdade dos fatos. Feita uma apresentação individualizada dos chefes dos partidos da província com que Montalvão Mascarenhas teria que tratar, elaborou o seguinte comentário:

Tímon termina aqui esta pequena galeria, não simplesmente de contemporâneos, senão de personagens verdadeiramente históricas, e já do domínio do passado; e lisonjeia-se de que do estudo destes tipos ou modelos possam os presentes e os vindouros tirar lições proveitosas para as suas relações políticas e para a prática dos negócios em geral. (LISBOA, 1864, p. 251)

Lisboa encetou nessa reflexão uma defesa do próprio trabalho, as personagens seriam "verdadeiramente históricas" e do domínio de um tempo que, embora já "passado", estavam ali por ele recordado para dar conta do que aconteceu e servir de lição para a política e os negócios da época. Mais uma vez, a visão de uma história utilitária foi chamada para a ordem do texto histórico. A colocação de eventos pretéritos como fontes de "lições" e parâmetro para julgar ações contemporâneas ia na esteira da já aludida função judicativa que se atribuía ao tribunal da história, marcando uma posição para o que passou no presente. Partindo do presente, Lisboa se dirigiu ao passado para interpretar aquele mesmo presente, na expectativa de um futuro outro que não a perpetuação dos vícios. A história da Província do Maranhão permanecia em aberto.

O centro das reflexões de Lisboa era a história da província e, como lembrou Jussara Silva (2017, p. 124), tais reflexões condensavam disputas historiográficas que eram igualmente disputas pelo presente. A narração do presente por Lisboa era diferente da narração de Magalhães, para tomar um exemplo já mencionado neste trabalho. Enquanto o poeta narrou um período de convulsões que fazia parte de uma época de transição na história política do país e da província em particular, a história pensada por Lisboa em Partidos $e$ eleições... objetivava algo diverso e vislumbrando um futuro. As narrativas de ambos diferiam em muitos aspectos: conteúdo, forma, meio de publicação, público, escopo. A interpretação mais conservadora de Magalhães ilustrava o difícil processo pelo qual a administração imperial afirmou a necessidade do 
Estado brasileiro, num contexto de rebeliões em vários pontos do território que exprimiam as fragilidades para consolidar esse poder (ALENCASTRO, 1989, p. 7). Tratando de outro assunto, o caso de Partidos e eleições... apontava também posições políticas diferentes, Lisboa era do grupo liberal e essa orientação aparecia em suas produções. Assim, a indicação de Magalhães aqui tem a ver com as possibilidades de se escrever sobre o presente no âmbito da história local, qual seja a temática ou abordagem.

Escrever a história do presente da província começava pela identificação das práticas contemporâneas com o passado que conheceu ações análogas. A história do presente efetuada por Lisboa era um libelo contra essa situação em vias de se perpetuar diante de seus olhos e da posteridade. A proposta do autor era corrigir ou ao menos emendar os costumes provinciais, pois ainda que se encontrasse desalentado da vida pública, seu pessimismo não o impedia de "acreditar na capacidade de reforma dos costumes pela ação do próprio homem" (CARVALHO, 1995, p. 19).

A crítica aos vícios da política provincial e sua consequente reprodução do poder na província "sob as vestes de um regime representativo" (TURIN, 2018. s/p) se estendia a todo o Império e ao Maranhão em particular. Lisboa encarnou em Partidos e eleições... a denúncia largamente feita à época valorizando o tripé violência, manipulação e fraude para tratar do processo eleitoral, o que dificultaria a plena realização do governo representativo no Brasil.

O peso relativo de cada um desses elementos variou com o tempo e essa variação foi notada pelos contemporâneos (LIMONGI, 2014, p. 16), em Lisboa eles ocupavam a cena principal, ainda que tenha falado que certos costumes como as falsificações de alistamentos estavam caindo em desuso, continuando praticadas apenas por "gente simples e pouco civilizada" (LISBOA, 1864, p. 326). A avaliação tinha a ver com a questão ampla da representação, de quem podia votar e ser votado e como se dava essa dinâmica. Imperava a crença de que a qualidade do governo dependia diretamente da qualidade dos eleitores e dos representantes escolhidos (DOLHNIKOFF, 2009, p. 42-47), esperava-se 
que ambos fossem dotados de discernimento para eleger e ser eleito, o que, na prática, traduzia-se por capacidade intelectual e material, possuir renda suficiente e uma rede de conexões locais, elemento este que articulou a narrativa de Partidos e eleições.... Os argumentos políticos mais difundidos eram os que definiam os votantes - participantes da primeira fase das eleições e que elegiam os eleitores que, por sua vez, escolhiam os representantes - como dependentes, incapazes e ignorantes (MOTTA, 2018, p. 168).

É interessante pontuar que Partidos e eleições... foi publicado nas margens da implantação do Gabinete da Conciliação (1853-1868), uma política que buscou apaziguar as disputas reunindo o Ministério com liberais e conservadores, reformulando o sistema partidário no país (MOTTA, 2018, p. 152). O quanto que essa discussão poderia ser expressa no trabalho de Lisboa daí em diante foge ao escopo deste artigo, basta reter que ele era sensível ao estado político-partidário mais abrangente.

A crítica também se dirigia ao discurso da capital São Luís como a "Atenas brasileira", projeto acalentado por grupos da sociedade no período imperial. Tomando-a como uma falsa representação, falou de uma sociedade que se destacava pela corrupção, abuso de interesses pessoais, violência, pobreza, portanto, o contrário da imagem civilizada que se queria veicular. Num Maranhão marcado pela escravidão e certo isolamento com relação à Corte instalada no Rio de Janeiro, a criação de uma Atenas brasileira foi uma escolha consciente desses grupos que privilegiava traços europeizantes em prejuízo dos aspectos indígenas e africanos. Para Henrique Borralho (2009, p. $18)$ :

a Athenas foi a forma como os maranhenses participaram do jogo da construção identitária nacional sem que necessariamente a herança cultural de Portugal fosse relegada. Nesse âmbito, no difuso processo de construção do que era ser brasileiro em terras maranhenses, o passado lusitano foi rechaçado quando interessou a comerciantes, funcionários públicos e demais setores eliminarem suas dívidas, ocuparem cargos e disputarem espaços de poder, para depois ser recomposto enquanto simbolização dos ícones de uma grande nação, incluindo as características que poderiam fazer do Brasil páreo ante as nações vizinhas do continente. 
A denúncia de Lisboa se fez sob um aparato historiográfico, o presente da província o motivou a estudar e escrever sobre história, depois de abandonar a atuação partidária e a lide no jornalismo político local. Nesse caminho estava o objetivo pragmático de tentar corrigir os costumes provinciais, trazendo exemplos legados pela história da humanidade que considerava pertinentes para chegar à situação de sua região, o "obscuro canto" do mundo que habitava, como por vezes se reportou ao Maranhão.

Aos que lhe criticassem, Tímon já se defendeu:

Pelo que toca ao descrédito e difamação da terra que nos viu nascer, não tenho admiração para o vício pudibundo, que cora até a raiz dos cabelos, e cobre com as mãos ambas o rosto turvado de uma ingênua e amável confusão! Mas quem ousaria, a não serem os cúmplices do mal, os culpados impenitentes e relapsos, quem ousaria negar, encobrir, ou ainda simplesmente dissimular a degradação e opróbrio a que temos chegado, e hão feito de nós a fábula e o baldão da corte e do império todo, da corte especialmente, que a tantos respeitos nos trata com o desprezo de que somos dignos? Consiste por ventura o patriotismo, ou provincialismo, em negar impudentemente uma verdade conhecida por tal, ou antes confessar nobremente o mal, e da grandeza dele tirar motivo e ocasião para reclamar a emenda e reforma a grandes brados? (LISBOA, 1864, p. 427-428)

A postura do autor em se colocar à parte dos que pregavam a civilização maranhense enquanto herdeira direta da civilização europeia ficou evidente nessa passagem do texto colocado ao final do folheto, intitulado Tímon a seus leitores. Dirigindo-se diretamente ao público, ofertou sua visão acerca da posição que a Província do Maranhão ocupava no Império. O excerto é também oportuno por sinalizar uma disputa pela narrativa da história provincial e em sua relação com a Corte, a investigação do passado se tornou objeto de uma disputa que reverberou no presente. Porém, mostra-se interessante notar que, a revelia da própria crítica, ele mesmo em algumas ocasiões se colocou como um "grego", como no seguinte trecho do já citado Prospecto:

Será talvez oportuno explorar então alguns pontos da história antiga e moderna deste povo, pequeno e obscuro sim, se o comparamos com tantos outros, porém o maior, e o mais celebrado que pode haver, para um grego nascido e criado 
nas históricas margens do soberbo Itapecuru. (LISBOA, 1864, p. 10)

Este aspecto aponta para contradições dentro da narrativa de Lisboa, marcada por mudanças de posição ao longo da escrita de seus trabalhos. O que queria chamar atenção, contudo, é que tocando em questões essenciais como a da composição da sociedade maranhense, o lugar que cabia a brancos, índios e negros, estava sendo discutida qual interpretação se deveria dar para a história colonial da província, uma interpretação que contava não só para uma demanda local, mas também na produção da história nacional. Num momento em que se tentava delinear uma identidade nacional e imprimi-la na narração historiográfica, muitas vezes a história pátria era primariamente a história do local de nascimento. Havendo uma multiplicidade de formas de escrever, Lisboa podia fazer uma história das práticas e costumes eleitorais de sua província natal sem entender com isso que estava produzindo uma história regional e não nacional (BATALHONE JR., 2003, p. 8).

\section{Considerações finais}

A narração do presente em Lisboa tinha uma finalidade além da pesquisa histórica em si, ela almejava uma atuação direta na condução de uma reforma moral da vida da província maranhense. A opção por escrever a história das eleições provinciais cumpriu não apenas o requisito de "ser um tema familiar aos seus leitores, mas também por condensar as relações entre as diferentes camadas sociais permitindo a construção de uma ideia geral sobre a província" (SILVA, 2017, p. 136), Lisboa intencionou abarcar o que ele considerava representativo da sociedade maranhense, em especial da capital São Luís, representativo ao menos do que ele queria mostrar e do ponto de vista que adotou. Porém, isso não significava estar desatento às questões que um relato sobre o presente envolvia naquela conjuntura, não por acaso a narrativa de Partidos e eleições... não revelava as datas precisas dos acontecimentos tratados. Importava que a sociedade se conscientizasse da batalha ininterrupta entre os princípios do bem e do mal (SANTOS, 2000, p. 245), da civilização e 
da barbárie. Querendo emendar e corrigir os costumes políticos via pintura dos costumes públicos, Lisboa fez uma crítica contundente ao formato do sistema representativo da monarquia constitucional cujas premissas formais modernas pareciam não funcionar em regiões remotas já controladas pelas elites mais tradicionais (TURIN, 2018, s/p). Os mesmos grupos que uma vez tiraram seu nome da corrida pelo posto de deputado.

Pertencendo a uma geração que precisou elaborar uma narrativa histórica para o país recém-independente e os protocolos metodológicos para essa escrita (TURIN, 2018, s/p), o trabalho de Lisboa expressava a variedade da historiografia no Brasil imperial, dadas as indefinições e variações dos próprios modos de enfrentar os problemas da produção histórica da época. Um momento fértil de tensões políticas que acabavam reverberando na escrita histórica, sendo uma delas a matéria sobre a qual se debruçou o folheto, o tempo presente.

\section{Referências}

ALENCASTRO, Luís Felipe de. Memórias da Balaiada. Introdução ao relato de Gonçalves de Magalhães. NOVOS ESTUDOS, São Paulo, n. 23, p. 7-13, mar. 1989.

ARAUJO, Valdei Lopes de. A experiência do tempo: conceitos e narrativas na formação nacional brasileira (1813-1845). São Paulo: Aderaldo \& Rothschild, 2008.

ARAUJO, Valdei Lopes de. Historiografia, nação e os regimes de autonomia na vida letrada no Império do Brasil. Varia História, Belo Horizonte, v. 31, n. 56, p. 365-400, mai./ago. 2015.

BATALHONE JR., Vitor Claret. O Brasil de Lisboa. Anais do X Encontro Estadual de História, Santa Maria, 2003.

BORRALHO, José Henrique de Paula. A Athenas Equinocial: a fundação de um Maranhão no Império brasileiro. Tese (Doutorado em História). Departamento de História, Universidade Federal Fluminense, 2009.

CARVALHO, José Murilo de. Lisboa e Timon: o drama dos liberais do Império. In: LISBOA, João Francisco. Jornal de Timon: partidos e eleições no Maranhão. São Paulo: Companhia das Letras, 1995.

CEZAR, Temístocles. Escrita da história e tempo presente na historiografia brasileira. DUTRA, Eliane Freitas (Org.). O Brasil em dois tempos. História, 
pensamento social e tempo presente. 2013. Disponível em: https://www.google.com.br/books/edition/O_Brasil em dois tempos/F6EkDw AAQBAJ?hl=pt-BR\&gbpv=1\&printsec=frontcover. Acesso em: 24/05/2021.

DE CERTEAU, Michel. A escrita da História. 3. ed. Rio de Janeiro: Forense, 2017.

DOLHNIKOFF, Miriam. Representação na monarquia brasileira. Almanack Braziliense, São Paulo, n. 9, p. 41-53, mai. 2009.

GUIMARÃES, Lúcia M. Paschoal. Debaixo da imediata proteção de Sua Majestade Imperial: o Instituto Histórico e Geográfico Brasileiro (1838-1889). RIHGB, Rio de Janeiro, n. 388, jul./set. 1995.

HARTOG, François. Evidência da história: o que os historiadores veem. Belo Horizonte: Autêntica Editora, 2013.

IHGB. Extratos das Atas. RIHGB, Rio de Janeiro, Tomo IX, 1847. Ata da sessão de 16 de fevereiro de 1850. RIHGB, Rio de Janeiro, Tomo XIII, 1850.

JANOTTI, Maria de Lourdes Mônaco. João Francisco Lisboa: jornalista e historiador. São Paulo: Ática, 1977.

KOSELLECK, Reinhart. Estratos do tempo: estudos sobre história. Rio de Janeiro: Contraponto; PUC/RJ, 2014.

LIMONGI, Fernando. Revisitando as eleições do Segundo Reinado: manipulação, fraude e violência. Lua Nova, São Paulo, n. 91, p. 13-51, 2014.

LISBOA, João Francisco. Obras de João Francisco Lisboa. v. I. São Luís: Tipografia de B. de Mattos, 1864.

LISBOA, João Francisco. Obras de João Francisco Lisboa. v. II. São Luís: Tipografia de B. de Mattos, 1865.

MALEVAL, Isadora Tavares. A "arca do sigilo" do Instituto Histórico e Geográfico Brasileiro oitocentista. Anais do XXVII Simpósio Nacional de História da ANPUH, 2013.

MOTTA, Kátia Sausen. Eleições no Brasil do Oitocentos: entre a inclusão e a exclusão da patuleia na cidadela política (1822-1881). Tese (Doutorado em História). Centro de Ciências Humanas e Naturais, Universidade Federal do Espírito Santo, 2018.

SANTOS, Maria Rita. Uma leitura pragmática do Jornal do Timon de João Francisco Lisboa. São Luís: EDUFMA, 2000. 
SILVA, Jussara Rodrigues da. Reformar os costumes pela história: a historiografia de Francisco Lisboa no Jornal de Timon. Tese (Doutorado). Programa de Pós- Graduação em História, Universidade Federal de Ouro Preto, 2017.

TIBURSKI, Eliete Lucia. Escrita da história e tempo presente no Brasil oitocentista. 146 f. Dissertação (Mestrado em História). Programa de Pósgraduação em História, Universidade Federal do Rio Grande do Sul, 2011.

TURIN, Rodrigo. Uma nobre, difícil e útil empresa: o ethos do historiador oitocentista. História da Historiografia, Ouro Preto, n. 2, mar. 2009.

TURIN, Rodrigo. João Francisco Lisboa (1812-1863). In: PARADA, Maurício; RODRIGUES, Henrique Estrada (Org.). Os historiadores: clássicos da história do Brasil. v. 4. Petrópolis: Vozes, 2018. Disponível em: https://www.google.com.br/books/edition/Os_historiadores_Cl\%C3\%A1ssicos _da_hist\%C3\%B3ria/6PhNDwAAQBAJ?hl=pt-

BR\&gbpv=1\&printsec=frontcover. Acesso em: 24 jul. 2021.

VARNHAGEN, Francisco Adolfo de. Os índios bravos e o Sr. Lisboa, Timon $3^{\circ}$. Apostila e nota G aos no 11 e 12 do "Jornal de Timon"; contendo 26 cartas inéditas do jornalista, e um extrato do folheto "Diatribe contra a timonice". Lima: Imprensa Liberal, 1867.

Recebido em: 04 de maio de 2020 Aceito em: 29 de junho de 2021 